\title{
Prior Performance and Corporate Governance Characteristics of Acquirers
}

\author{
Jürgen Kurth \\ Faculty of Economics and Business Administration, Maastricht University, \\ P.O. Box 616, 6200 MD Maastricht, The Netherlands \\ Thorsten Lehnert ${ }^{*}$ \\ Limburg Institute of Financial Economics (LIFE), Maastricht University, \\ P.O. Box 616, 6200 MD Maastricht, The Netherlands \\ Nijmegen School of Management, Radboud University Nijmegen, \\ P.O. Box 9108, 6500 HK Nijmegen, The Netherlands
}

This version: September 2006

\begin{abstract}
Recent empirical research has proposed a variety of factors that explains the decision of companies to merge or acquire. We use a binary logistic regression framework to investigate the effects that prior firm performance, prior resource availability, and corporate governance characteristics have on the propensity of a company to become active. The analysis focus on American companies in the timeframe from 1997 until 2006 and compare the active companies to a set of inactive peers. In line with previous research, results suggest that poorly performing companies show a higher probability to demonstrate activity in merger and acquisitions. Furthermore, we find support for the prediction that companies well endowed with financial resources and companies with inferior corporate governance show a higher propensity to engage in merger and acquisition activities.
\end{abstract}

Keywords: Merger \& Acquisitions, Corporate Governance, Prior Performance, Binary Logistic Regression.

* Correspondence to: Tel: +31-43-3883838; Fax: +31-43-3884875. E-mail: t.lehnert@finance.unimaas.nl. 


\section{$1 \quad$ Introduction}

The majority of academic literatures focusing on merger and acquisition activities have dealt with post merger results of these activities (e.g. Jensen (1988)). Only few studies have tried to investigate the reasons why companies became active or stayed inactive, or why some firms became an attractive takeover target. Powell (2004) and Weir (1997) have analysed the pre merger conditions of takeover targets and have found that firm size, prior performance, and corporate governance control structures have had impacts. Concerning the pre merger conditions of the bidding, or acquiring companies, the academic literatures seem to agree on the fact that these companies are usually larger in size than the inactive ones (e.g. Park (2003)), they usually tend to have the required resources needed to accomplish the acquisition process (e.g. Haunschild (1993)), and the companies likely have already had some experience with mergers and acquisition activities in the past. Furthermore, it appears that mergers occur in waves and that activities in some industries are more likely to take place than in others (e.g. Holmstrom and Kaplan (2001)). Next to these already relatively established variables that explain activity in merger and acquisition processes, Morck et al. (1990) have highlighted that a previously experienced bad company performance will increase the probability to get active, opposite to the predictions of Roll’s hubris hypothesis (Roll (1986)).

Next to these variables it is necessary to understand the underlying motivation of a company to become active in merger and acquisition negotiations. Usually the creation of synergetic effects should give a valid reason for a company to become active. If not, then Roll's hubris hypothesis explains that managers overestimate their own abilities of running a potential target, or they overestimate the probably created synergetic effects. Apart from this, academic literatures agree that in many cases merger and acquisition activities are accomplished to satisfy personal objectives of the management. Since this can only be the case in companies, where shareholders cannot monitor management, or is in any other way not able to eliminate an agency problem. This gives rise to presume that the level of corporate governance in a company should have an effect on the probability of a company to become active in merger and acquisition negotiations.

This study analyses the various factors that should have implications on the probability of a company to become active in merger and acquisition activities and will therefore provide answers to the questions: Which factors have a significant effect on the probability of a company to become active in merger and acquisition processes? What explains related or unre- 
lated acquisition activities? The study will focus especially on prior performance measures, on the prior resources availability, and on corporate governance.

The remainder of this paper is organized as follows. Section 2 will provide an overview of the literature and the theoretical backgrounds of merger and acquisition activities and on corporate governance issues. Section 3 explains the datasets and the methodology used in the analyses. Section 4 presents the empirical results. Section 5 highlights limitations of the analysis, comprised with possible approaches for further research and finally results and concludes.

\section{$2 \quad$ Literature, Theoretical Background and Hypotheses}

The expression merger and acquisitions refers to the strategic process of companies combining their business fields in the sense that they appear as one entity, or companies obtaining control of other organizations. In recent years, the numbers of activities have roughly been in the area of 1.000 to 2.000 per year. Lately, the biggest merger activities in the United States have been the fusion of America Online and Time Warner to the AOL Time Warner, the merger of Exxon and Mobil Oil to ExxonMobil, the merger of Citicorp and Travelers Group to the Citigroup and the integration of World Com and MCI World Com to MCI Communications.

Most corporate growth can be achieved by organic or inorganic growth. Organic growth relates to the steady internal expansion of existing activities, yielding in an increase in output and sales. Contrary to this also called core growth, inorganic growth describes the enlargement of corporations via mergers, acquisitions and take-over activities. These activities are usually carried out through a payment of cash, bonds, shares, or a mix of these three components of the bidding company (Ross et al. (1999)). A friendly merger or acquisition is achieved once the management of the acquiring company and the management of the target company jointly agree on the terms of the overall process. Following this, the two management groups will announce this agreement to their shareholders and the target management group will eventually suggest their shareholders to agree to the merger and to tender their shares to a financial institution to transfer the shares to the bidding firm. In exchange they will then collect the previously negotiated compensation. In contrast to a friendly merger, a hostile takeover excludes the management of the target company and addresses the shareholders directly. This occurs once the two managements do not come to an agreement, mostly because the target management decides that the offered price for the takeover is not suffi- 
cient, or just simply because the management does not want to lose their jobs. The acquiring company addresses the target shareholders using newspaper advertisements or just simply buys the shares at a stock exchange. A famous example of a hostile takeover is the acquisition of Mannesmann AG by the Vodafone Group in 1999.

Generally merger and acquisition activities can be classified into (1) horizontal, (2) vertical, and (3) conglomerate activities. Horizontal merger and acquisition activities occur once the acquiring company and the target company operate in the same line of industry. The recent acquisition of Aventis by Sanofi Systemelabor is a good example of a horizontal activity. A vertical activity describes the merger or an acquisition of companies that operate upward or downward in the industry cycle. An acquisition of a supplier for a company is an example. As opposed to a horizontal or a vertical merger, a conglomerate merger describes a combination of two enterprises that operate in independent industries. The true value for the shareholders is questionable. Companies might argue that a conglomerate merger will benefit the shareholders, since they can enjoy a more diversified and therefore saver investment. The academic literature questions this benefit. Morck et al. (1990) highlight that conglomerate mergers will rather not add shareholder value than destroy it and mostly benefit the management of the company.

Most of the academic literature on mergers and acquisitions detect (1) synergy, (2) agency, and (3) hubris as the three major motives for companies to undertake this process.

The most rational explanation of corporate merger or acquisition processes is to create synergy. This fundamental idea is achieved if the coalesced value of two previously separate entities is higher than the values of both companies taken separately. The most common seven sources for synergistic effects are in (a) operating economies, usually defined as results from economies of scale in various departments, often achieved by laying off personnel, (b) financial economies, as a possible result of lower transaction costs, (c) tax effects, if the tax burden by the combined entity is lower compared to the taxes payable for both separate entities, (d) the differential effect, indicating an increase in efficiency in management usually achieved by removing poorly performing managers, (e) an increase in market power, as a consequence of reduced competition, (f) the cross-selling motive, where a preferable complementary product of the acquired company can be offered in the same sales talk, and (g) diversification, either in a geographical or product line sense. These synergistic effects and motives for merger and acquisition activities are in almost all academic articles considered to 
add value for the shareholders, whereas agency and hubris are known to destroy shareholder value.

Merger and acquisition activities that are primarily induced by selfish objectives of the acquiring management are classified as agency motivated. The managers' objectives are numerous; one of the most prominent reasons for a merger activity is the fact that the management will diversify its on personal portfolios (Baumol, 1967). Apparently, the exposed risk to any changes in the industry environment will eventually diminish with more business fields the company will operate in. Hence, a conglomerate or vertical merger will be a better way to diversify than a horizontal merger for the managers to secure their jobs. Furthermore, a merging or acquisition activity will increase the company size and therefore will have a positive influence on the management's salary. Also, merger and acquisition activities are also executed due to the management's ego. Managing a bigger company will give the executives more power and more prestige. Additionally, Morck et al. (1990) highlights that poorly performing managers will try to buy in success, distract shareholders form their incompetence, and with an acquisition, they will try something new, hoping that they will do better than before. The terminology agency problem or agency theory describes the conflicting interests between managers and shareholders. As long as the management does not fully act in the interest of shareholders the agency problem arises. Usually the problem occurs in business settings in which the two parties have incomplete information. The concepts of adverse selection and moral hazard describe the agency problem best. Adverse selection describes the problem that the shareholders are unable to fully assess whether the management accurately performs and has the ability to work as proposed. Moral hazard describes that the shareholders are uncertain that the management has put forward his maximal effort.

The third often cited reason for managers to enforce merger activities is the hubris hypothesis. Roll (1986) describes the hubris hypothesis of corporate takeovers as mergers that were enforced due to managers' mistakes. These mistakes have significant effects on the valuation of the potential synergetic effects in an acquisition process. In case the management underestimates the synergetic effects, the potentially acquiring company will not get active, even though the possible effects were to give reason for an acquisition. In the case of the management overestimating synergy, shareholder value might be destroyed, since it might have been better to engage in other growth activities. The hubris hypothesis is not just related to the valuation mistakes of synergies, but also describes the overestimation of managers of their own abilities due to a recently experienced good performance of their company. In consequence, managers that overvalue their capabilities will eventually tend to overpay for tar- 
gets. Morck et al. (1990) and Shleifer and Vishny (2003) have questioned the validity of Roll's hubris hypothesis. Their prediction concerning the prior performance opposes the proposition of Roll and they find results indicating that poor prior performance will give managers an incentive to become active as described earlier. These contrary suggestions will be subject to the upcoming analyses in this study.

The United States have experienced five major merger waves in their history. The first one started in the late 1800s, where numerous mergers took place in the steel, tobacco, and oil industries. In the 1920s, the second merger wave occurred, due to a stock market boom. The third one was in the 1960s, where mostly conglomerate mergers took place. The forth merger wave happened in the 1980s and can be defined as a "hostile" takeover wave, where the acquirers have used cash as a medium of payment that was raised by bank debt and junk bonds in order to split up the conglomerates that were created in the 1960s, since they were regarded as being inefficient (Shleifer and Vishny (2003)). The last merger wave occurred in the late 1990s and the processes were usually financed with stock and had mostly shown industry related activities.

The last two merger waves are of special interest in this study, since they have had a great impact on the evolvement of the corporate governance subject, which will be further described in the upcoming section. As mentioned, the merger wave of the 1980s can be described as a hostile merger wave with a great use of bank debt and junk bonds to finance the activities. This had a severe effect on the leverage of the companies, a debt level exceeding 80 percent of the total capital was considered to be normal (Holmstrom and Kaplan (2001)). Corporate structures at that time gave the managers little reason to focus on shareholder concerns; the management was rather loyal to the corporation (Jensen (1993)). Furthermore, internal incentives to tie management compensation to the stock performance were rare, only 20 percent of the compensation of chief executive officers was tied to performance measures in 1980 (Hall and Liebman (1998)). Lacking closer monitoring and considering shareholder value to be an enemy, the acquisition volume increased in 1988 to 10 percent of average total stock market capitalization. Additionally, the rate of issuance for junk bonds, of which more than 50 percent were used to finance merger and acquisition activities, can in many years of the 1980s be expressed to be of an annual level of close to 1.5 percent of the average stock market capitalization. Much of the issued junk debt went into default and cost investors millions of dollars. At the time of the merger wave of the late 1990s, shareholder value was no longer considered to be an enemy. A lot of corporate governance issues had been imple- 
mented and almost all recent mergers had been stock-for-stock. Takeover activity was no longer caused by failure of internal governance mechanisms in organizations, but was a consequence of investors' exaggerated predictions about future growth potentials of companies, especially of those firms that were active in the information technology industry. Therefore, share prices of these companies increased tremendously, giving these companies the opportunity to use their high market capitalization to acquire less high valued companies. The media and even investors started to question well established financial principles. The terminology "new economy" differentiated companies with high growth potential from those companies that were well established and followed a value strategic approach. The new economy seemed to follow other rules than the established fundamentals, thus an observed price to earnings ratio of 50 and even higher was not unusual and was explained with the growth potential that this decade full of technological innovation was to bring. Recent past proved that the basic financial principles still apply to all organizations, and share prices of companies with high growth potentials fell to normal levels or even below. In the case of an acquisition of a value company by a growth company during that time, the shareholders of the bidding company were in the long run better off with the deal, since they traded in some questionable growth potential and gained a business that pursuit a steady value creating approach.

Merger and acquisition activities are generally considered to have increased the overall efficiency of the corporate sector. Even the merger wave of the 1980s is retrospectively considered to have had a positive effect in terms of efficiency. Furthermore, the evolvement of the corporate governance subject was positive, since it forces the management to focus on shareholder value. Nevertheless, academic articles that looked especially at corporate results show mixed findings assessing the success of merger and acquisition activities. Berkovitch and Narayanan (1993) find that on average, takeovers yield positive total gains. 75 percent of the takeovers in their sample approve this statement. Contrary, Galpin and Herndon (1999) report that just 23 percent of all acquisitions earn their cost of capital, and that the projected synergies were not achieved in 70 percent of the cases. Furthermore, Berger et al. (1995) finds that mergers motivated by diversification effects do not increase the firm's value. Lang and Stulz (1994) highlight that in many cases firms are not as much worth as their individual parts after the merger. Numerous companies that had realized that the merger or acquisition did not benefit the company have parted again. A famous recent example is the break up of Adidas-Salomon, the merger never met the projected synergies and cost the shareholders millions of Euros. Another classical example of a failed merger process is the acquisition under- 
taken by the automotive company DaimlerChrysler and the Mitsubishi Motors Corporation (Schneider and Barsoux, 2003). The failure of this merger can be pinpointed to the fact that managers did not understand to take care of cultural differences in the two companies. Again, the failure cost shareholders millions.

These results imply that a merger or an acquisition can be defined as generally a risky organizational decision. It is comparable to an investment decision, but the outcome is harder to predict and not easy to be quantified in a net present value, economic value added or in any other scenarios.

Concerning the effects and results of merger and acquisition activities on the shareholders of the bidding and the target companies, the academic literature agrees that the target shareholders increase their wealth, but there is a debate as to whether mergers benefit the acquiring firm's shareholders. Various studies have analysed post merger results and generally it has been shown that the acquirers gave away all of the synergies from the mergers to the acquired firm's shareholders (Henry (2002)). Berkovitch and Narayanan (1993) find that the returns to acquiring firm stockholders are even negative in about half of their studied sample. Jensen (1988) gives a very comprehensive summary on the results of various previous works and confirms the notion that takeovers are beneficial for target companies. Premiums in hostile merger and acquisition processes have even exceeded 30 percent on average. Acquiring firms' shareholders earn nothing in mergers, but have earned about 4 percent in hostile takeovers. Therefore, these results give reason to question the overall benefit for the acquiring company and it appears that managerial objectives have great impacts in merger and acquisition negotiations. Taking the exposed risk and the little, if all existing returns to bidding companies' shareholders into consideration, the results call for more monitoring of the management and for generally more rights to the shareholders. Following this argumentation, the next section will deal with corporate governance issues.

The already described merger wave in the 1980s and all the peripheral activities that were involved in it, and the ever increasing significance of capital markets due to an increased number of institutional investors had set off corporate governance activities. Throughout the last 25 years many rules and regulations have defined a framework in which an organization can operate and in which internal and external authorities can monitor decisions made by corporate managers. Even though corporate scandals have cost shareholders and creditors millions, the scandals always disclosed gaps and shortcomings of corporate governance control systems and had therefore been beneficial to the overall evolvement of corporate govern- 
ance. In the United Kingdom the failures of Polly Peck, BCCI, and the Maxwell Empire in the late 1980s and early 1990s, have lead to set up the Cadbury Committee to investigate the problem of financial reporting and to set up stricter practices than used before (Weir (1997)). The latest scandals of Enron, WorldCom, Arthur Andersen, Tyco, Parmalat, just to name a few, have shaken investors' trust severely and have called for further reforms of internal and external corporate governance mechanisms.

Academic literature has developed many versions of definitions of corporate governance. Holmstrom and Kaplan (2001), describe corporate governance simply as the mechanisms by which corporations and their managers are governed. Shleifer, and Vishny (1997) explain that corporate governance deals with the ways in which suppliers of finance to corporations assure themselves of getting a return on their investment. Recapitulating, almost all the definitions given agree upon the fact that corporate governance deals with rules, procedures, policies, laws and institutions that have an effect on how a company is administered, controlled and directed. Most of the definitions involve the relationship among the main stakeholders of a corporation, including the management, shareholders, employees and the board of directors. At large, most of the focus of corporate governance is to guarantee that the managers of a corporation act on behalf of the shareholders and employ the principles of value-based management to increase and maximize shareholder value. In short, the broad focus is on the principal agent conflict, or simply agency theory. A high level of transparency, good auditing and control and accountability are the most important attributes to assure good corporate governance. In many ways the compliance to codes and standards in various areas of business can help achieve a high level of corporate governance. This level should lead to an optimization of results, by generating superior returns and economic performance and by lowering the cost of capital of a corporation (www.gmi.com). Among others, Merret and Houghton (1999) highlight the reflective consequences of the separation of ownership and control and the nature of corporate governance. Being able to control and detain the management to act in their best interest and not in the interest of the shareholders is of greatest importance.

The parties involved to achieve good corporate governance can be classified in the context of internal and external control mechanisms. The internal controls are undertaken by the board of directors, audit committees, and remuneration systems. The board of directors have the legal authority to hire and fire managers and regular board meetings should monitor the activities of the management. As the Cadbury Committee (1992) discusses, the composition of the board of directors is very important. Firstly, the role of the chairman and the chief 
executive officer need to be separated. Second, the non-executive officers needed to be able to work independently, and finally, the officers needed to be of high quality. The 1980s had shown that non-executive board members were usually cosy with management, since they were often managers of supplying companies and had the same interests as the chief executive officer (Holmstrom and Kaplan (2001)). The results were already discussed in the previous section. Nevertheless, the negative side of having a strong board with a lot of monitoring activities is that the management is lacking flexibility and that monitoring costs a lot of money. Next to the board of directors, the audit committee is an internal control mean to monitor management. These internal auditors need to supervise the financial reporting and need to make sure that the management is not able to change financial figures to trick investors. Lacking capable internal auditors, or worse having auditors collaborate with the management as in the case of Arthur Andersen, might lead to creative accounting practices and will show misleading financial reporting. Furthermore, a performance-based remuneration, where a portion of the management's salary is related to the company's performance will create an incentive for the managers to work in favour of the shareholders. This objective is best achieved in the form of non-cash payments such as shares or share options that usually show high correlation with a company’s performance.

The external corporate governance control is undertaken by external auditors, government regulations, takeovers, and the managerial labour market. External auditors and government regulations are at large represented by the US Security and Exchange Commission and tax authorities. These parties will act in a similar way as the internal auditors of the company, but have no direct influence on managerial decisions as long as the managers act in legal contexts. Takeover threats and the managerial labour market are a strong external control and the financial market is the party that has the greatest influence. As soon as institutional investors or rating agencies punish managers for bad managerial work, share prices might drop and the organization becomes an interesting takeover target for other companies. Additionally, weak performance and a well endowed managerial labour market might lead to a fast replacement of the managers.

The latest corporate scandals have alarmed investors and have put the spotlight even more on corporate governance practices. Even though a lot of changes occurred lately, regularity institutions, investors and the academic community asks for further reforms. It appears that still a lot of changes need to be implemented to diminish the agency problem. Nevertheless, the latest improvements are rewarded by the fact that more and more investors think that cor- 
porate governance issues are of great importance. The Global Investor Opinion Survey (McKinsey (2002)), has found that 80 percent of investors are willing to pay a premium for well-governed firms. The level of corporate governance in a company is to many investors of equal importance than the financial figures of the firm. Investors seem furthermore not just to focus on particular governance practices of certain companies, but country-level factors such as the level of corruption or accounting standards seem to be of great significance as well. Internationally, Canadian companies were seen to be a desirable investment, whereas Russian, Egyptian, and Moroccan companies were seen to be the least favoured. These results show that investors are very well aware of the incorporated risk in investments and that wellgoverned firms are worth paying a premium, since the risk of not collecting a return on the investment will be diminished with employed governance structures.

As in the previous section presented, the majority of investors assess information on corporate governance practices of firms as valuable. To provide these investors with the information needed, various corporate governance rating agencies have emerged and previously solely financial figure focused rating agencies such as Standard and Poor's or Moody's have decided to participate in the governance rating business as well. Standard and Poor's generates a Corporate Governance Score (CGS) based on 250 governance-related variables from four basic categories. These categories are ownership structure and influence, financial stakeholder rights and relations, financial transparency and disclosure, and board structure and process. The firms will pay for the rating, since Standard and Poor's intention is to inform the company primarily, not possible investors. The rating result will then just be presented to possible investors, if the company makes that information public (Drake (2003)).

Moody's approach is somewhat different. The organization will not issue separate corporate governance scores, but will increase discussion of governance issues in public and private releases in their credit analyses (Bertsch (2005)). The companies' evaluations are done using 12 main criteria, focusing on the board structure, management compensation, and internal audit controls. Next to the rather new participants in the rating business, a rather established agency for the European market is the Belgian rating agency Deminor. The agency uses more than 300 criteria to evaluate a firm's governance level, categorised in four main criteria, namely board structure and functioning, rights and duties of shareholders, range of takeover defences, and disclosure on corporate governance. There are three established rating agencies in the United States. GovernanceMetrics International (GMI) even provides ratings for non US companies. GMI uses about 600 variables and rates companies on a scale from 1-10. In 
contrast to Standard and Poor's, it is not the firms that need to pay for the rating, it is the investors that do so. Next, the Corporate Governance Quotient (CGQ) is presented by the rating agency ISS. ISS operates similar to GMI, but does not disclose ratings to the media. Again, as in almost all cases, the CGQ is calculated from board composition, audit controls and compensation. Overall, the various performed ratings all agree more or less on the variables used to calculate the result. The last player in this rating business, and whose ratings will be used in the forthcoming analyses of this study, is the Investor Responsibility Research Corporation (IRRC). The created Governance Index focuses broadly on similar measures as the other agencies, but the actual rating is rather a system that adds up the number of distinct corporate governance provisions and is therefore straightforward: one point is added for every provision that reduces shareholder rights (Gompers et al. (2001)). Hence, the higher the Governance Index, the poorer the company’s governance control criteria.

Most of the academic literatures that investigated effects of corporate governance focused on the performance of the companies (e.g. Bauer et al. (2003) and Morck et al. (1989)). Most of these studies' results have found that performance decreases with poorer governance structures. Taking the proposed positive relationship by Morck et al. (1990) of poorly performing companies on the possibility to become active in merger and acquisition processes as given, then indirectly all work just focusing on performance should have found a positive relationship of poorly performing companies in terms of corporate governance on the probability of becoming active in merger and acquisition processes. Little academic work has been done to investigate this relation. Powell (2004), and Weir (1997) investigate the corporate governance structures and the prior operating performance not of acquirers, but of possible target companies. Gompers et al. (2001) have found evidence that a lower level of corporate governance is related to lower stock return, as other studies have stated as well, furthermore, they state in their study that weaker shareholder rights are associated with a higher amount of corporate acquisitions. These results will serve as motivating factors to derive some of the hypotheses used in this study.

To have a complete foundation to derive the hypotheses, it is necessary not just to present a fully comprehensive description of merger and acquisition activities and corporate governance, but also to elaborate on risk theory, since a merger and acquisition activity is associated with considerable risk for the company. The high probability of failure were not just to have consequences for the shareholders of the company, but possibly were to have 
severe consequences for the management as well. Therefore, it is necessary to understand under which circumstances individuals are motivated to undertake risky decisions. The prospect theory (Kahneman and Tversky (1979)) captures people’s attitudes to risky gambles (Barberis and Thaler (2002)). It appears that individuals tend to show a higher risk aversion involving choices with sure gains and risk seeking in choices with sure losses. Furthermore, the sure losses and sure gains could be seen as states of success and failures in real life. Transposing this theory to the probabilities of becoming active in merger and acquisition processes, managers might become more risk taking after experiencing a state of failure. This state of failure might be represented by bad prior performance and the higher risk taking propensity might be represented by an activity in a risky endeavour, possibly mergers and acquisitions.

Overall, this study intends to identify variables that explain the activity or inactivity of companies in merger and acquisition processes. Since academic literatures have already derived various theories, the already established variables used in these theories do not need to be formally derived again and tested in hypotheses. Nevertheless, the contradicting theories of Morck et al. (1990) and Roll (1986) give reason for the first hypothesis:

- Hypothesis 1: The probability of a company to merge with or to acquire another company increases, the lower the company's prior performance was.

It is expected that the results will support the theory of Morck et al. and will reject Roll's hubris hypothesis. The companies' prior stock return and the companies' return on assets will serve as measures to describe the performance in the empirical part of this paper. The variable return on assets has been used in various previous studies and is therefore a rather established measure. The stock return is chosen as a measure, since it is a very visible and apparent variable. Furthermore, the predictions by Roll assume perfect operating capital markets, therefore this variable should be a good measure.

Hypothesis 2's motivation is to focus on a possible increase in risk taking of the management due to prior experienced bad performance. Therefore: 
- Hypothesis 2: The probability of a company to merge with or to acquire another company being active in an unrelated industry increases, the lower the company's performance in comparison to companies getting active in related industries was.

From risk theory, it is expected that individuals that have experienced failure will tend to be more risk seeking. The more intense the experienced failure, the more risk seeking they are expected to act. Since a merger and acquisition activity in an unrelated business is generally understood to be of more risk to the company than a related activity, it can be expected that managers in desperation might prefer to even take on more risk, since they do not have too much to lose. Furthermore, Morck et al. (1990) highlight that managers experiencing bad performance will yearn to find something new that they might be better at.

Hypotheses 3 and 4 will focus on corporate governance issues. The variable used in the analyses to measure the level of corporate governance is the governance index constructed by Gompers et al. (2001). It is intended to find a positive relationship of a low level of corporate governance and merger and acquisition activity, hence:

- Hypothesis 3: The probability of a company to merge with or to acquire another company increases, the weaker the company's shareholder rights are.

The underlying reasoning is that managers are better able to pursue their own goals, when shareholders do not have any means to stop them. The lower the voting rights or monitoring abilities of shareholders, the lesser the managers will care about shareholder value. Furthermore, since various studies have proven that companies with a lower level of corporate governance have shown lower operating performance, and due to expected supportive results concerning hypothesis 1 , it can be expected that hypothesis 3 will be supported as well.

As the power of the shareholders diminish even further and managers even see themselves in a state of increased protection towards unemployment or also against other competitors showing interest in the managers' firms due to golden, silver, or pension parachutes, hypothesis 4 will elaborate on this state, therefore:

- Hypothesis 4: The probability of a company to merge with or to acquire another company being active in an unrelated industry increases, the weaker the company's shareholder rights compared to companies getting active in related industries are. 


\section{$3 \quad$ Data and Methodology}

The underlying motivation of this analysis is to investigate the characteristics and the motivation of a company to merge with or to acquire another organization. Especially the past performance and the quality of corporate governance control mechanisms of a company are next to other characteristics of interest. The analysis will show which characteristics will have an effect on the probability of an organization to get active in an acquisition process. The sample under investigation should hence include both active and non-active companies. Active companies are therefore corporations that have officially announced an acquisition activity in the timeframe from January 1997 until March 2006. The composition of the non-active peers matching the acquiring companies is subject to the operating industry and the size of the active companies.

The data on merger and acquisition activities was retrieved from the Thomson Baker One M\&A Database. The database detected 11.972 activities in the United States in the timeframe from January 1997 until March 2006, in which the acquiring company obtained control over the target firm.

The data on corporate governance provisions was retrieved from the Investor Responsibility Research Centre (IRRC). The IRRC has rated 3667 companies since September 1990 and has focused on companies that are listed on the S\&P Super 1500 index. The S\&P Super 1500 index combines the S\&P 500, the S\&P MidCap 400, and the S\&P SmallCap 600 indices and forms a very broad and representative index of the U.S. equity market by covering approximately $90 \%$ of the U.S. market capitalization (www.standardandpoors.com). IRRC renews the "Governance Index" for every company that is active in the S\&P Super 1500 approximately every two years. The Governance Index is constructed on 24 distinct corporategovernance provisions (Gompers et al., 2001) ${ }^{1}$. In short, for every firm, a point for every provision that reduces shareholder rights is added. Therefore, the higher the Governance Index score of a company, the weaker the rights of the shareholders.

The criteria for the construction of the dataset for the empirical investigations of the active companies were that (a) the company was included in the Thomson Baker One M\&A Database, (b) the company was only once active in the timeframe from January 1997 until March 2006, since the focus of this study is on the characteristics why a company gets active

\footnotetext{
${ }^{1}$ All 24 corporate-governance provisions are defined in the Appendix
} 
and not on how often a company gets active. Furthermore, past acquisition activities have severe consequences on all financial data of a company and make it impossible to investigate the omnipresent reasons for subsequent acquisitions. Additionally, (c) the companies needed to have an IRRC Governance Index for the year in which they announced their acquisition activity $^{2}$, (d) the companies needed to have valid information on various financial data, which was retrieved from Thomson One DataStream ${ }^{34}$, and (e) the companies needed to have a non-active peer company, which had to operate in the same GICS industry (Global Industry Classification Standard) in order to control for industry biases and the peer needed to have a similar market capitalization one trading day prior to the announcement date of the acquisition, in order to control for size biases between the two samples ${ }^{5}$. The dataset for the nonactive peers needed to fulfil the same criteria as the active companies, except (a). In total, this resulted in a dataset for the empirical testing of 92 active and 92 inactive companies. The distribution of active companies across industries is shown in Table 1.

\section{[Table 1]}

Most acquisition announcements occurred in the industrials (GICS 20) and consumer discretionary (GICS 25) industries. Furthermore, Table 1 shows that 19 of the 92 activities can be classified as an unrelated acquisition. This is in line with findings of Andrade and Stafford (2001) that acquirers were typically in the same industry as their target in the late 1990s.

The purpose of this study is to analyze whether weak company performance and bad corporate governance will, next to other measurements, increase the probability of a company to become active in an acquisition process. Therefore, Activity is the dependent variable and a binary classification is chosen with the dependent variable being coded as 1 for companies being active and 0 for the non-active peer companies. In addition, a further distinct analysis is made with regard to the industry relatedness of the acquisition to discover possible variations that are attributed to the higher implied risk of unrelated acquisitions.

\footnotetext{
${ }^{2}$ A Governance Index of a maximum of one year prior to the acquisition announcement date was used whenever the data was missing.

${ }^{3}$ Companies with data deviating with more than two standard deviations from the mean of the original sample were defined as outliers and excluded from the analysis.

${ }^{4}$ Thomson One DataStream will be abbreviated DataStream in the remainder of the text.

${ }^{5}$ The closest peer in terms of market capitalization was chosen. Companies without a peer with a market capitalization in a propinquity of $\pm 30 \%$ to the active company were excluded. The peers needed to have valid financial data from DataStream, otherwise the next nearest peer in terms of market capitalization was chosen.
} 
In order to gain essential results to give an answer to the stated hypotheses, the variables Return on Assets and the variable Governance Index are of special interest and will be used in the model. In line with Morck et al. (1990), it is expected that especially poorly performing companies perceive the need to change or to get active in merger or acquisition processes. Therefore, the variable Return on Assets is expected to show a negative sign in the analysis, since better performing companies should stay inactive.

The variable Governance Index is included to analyse the effect of bad corporate governance on merger or acquisition activity. The underlying motivation to include this variable is that poorly governed firms limit the voting rights of shareholders and consequently give managers more autonomy in decision making processes concerning the organization. In that sense, managers will tend to be more eager to pursue their own goals and take on more risk, rather than to do what is best for the company. Therefore, managers are expected to acquire other companies to diversify their own personal portfolio, increase their salary, due to running a larger company, or just for prestigious reasons. Consequently, the variable Governance Index is expected to show a positive sign in the analysis, since a higher Governance Index should lead to more activity.

Academic literatures focusing on the possible factors that increase the probability of a company to become active in a merger or acquisition process have found various variables and consequently these mostly already established variables are used as control variables in the model (e.g. Berkovitch and Narayanan (1993), Haunschild (1993), Holstrom and Kaplan (2001), Park (2003) and Shleifer and Vishny (2003)).

First, prior resource availability seems to be a factor that most academic authors seem to agree upon. Obviously the acquiring company needs to have the resources to be able to accomplish the acquisition process and furthermore, financial resources can be used as a buffer for potential downside risk. Hence, prior resource availability seems to have a positive effect on the probability that a firm will become active. The analysis uses the variables Debt to Equity Ratio and the Current Ratio to measure prior resource availability.

The Debt to Equity Ratio is used, since it measures the financial leverage of a company. The ratio is equal to a company's total long-term liabilities divided by the shareholders' equity. Therefore, the ratio can be used as an indication which proportion of equity and debt the company uses to finance its assets. The data on the Debt to Equity Ratio was retrieved from DataStream, using the most current yearly data prior to the acquisition announcement. This variable's coefficient estimate in the analysis is expected to be negatively related to the 
probability of becoming active, since more debt obviously decreases the borrowing capacity of the company.

Since the Debt to Equity Ratio is a measure of long term liquidity, the Current Ratio is added to the model to measure a company's short term liquidity. The Current Ratio is a comparison of a firm's current assets to its current liabilities. Therefore, the ratio evaluates the capability of a company to meet short-term debt obligations. Generally, a company showing a Current Ratio of 1 to 1.5 is considered to have good financial short-term strength. Nevertheless, the ratio varies from industry to industry, but the higher the ratio, the more the company is able to meet short-term requirements. Similar to the Debt to Equity Ratio, the data on the Current Ratio was retrieved from DataStream and the analysis uses the most current data prior to the acquisition announcement. The variable's coefficient estimate is expected to be positive in the analysis, since a higher ratio explains a better financial situation.

Next to the variables describing prior resource availability, the Market to Book Ratio is added as a variable to measure the growth potential of a company. The Market to Book Ratio is the current share price divided by the book value per share and detects the capital market's expectation on the potential of a company's return on equity in the future. Companies' shares showing a Market to Book Ratio close to or slightly above 1 can be characterized as value stocks and companies' stocks with high Market to Book Ratios can be described as growth stocks. Since Morck et al. (1990) find evidence that poorly performing companies show a higher tendency to merge; consequently the poor performance should also have a negative effect on the share price, thus these companies should also have a lower Market to Book Ratio, compared to better performing peer companies. Furthermore, companies with a low ratio have limited ability to grow organically and might rather use financial means to invest than to payout profits as dividends to the shareholders, it might be expected that these companies will show a higher probability to engage in merger or acquisition activities. The expectation in the analysis of the variable's coefficient estimate is therefore negative. Again, the data was retrieved from DataStream, using the information one day prior to the acquisition announcement.

Finally, the Return on Assets as a performance measure is added to the control variables of the model. The Return on Assets percentage shows how profitable a company uses its assets to create revenue. Since Return on Assets seems to be a widely accepted measure to define company performances, it is preferred to other possible performance measures. Since a higher percentage will detect a better performance of the company, and according to Morck et al. (1990), managers experiencing a poor company performance will show a higher prob- 
ability to engage in acquisition activities, the variable's coefficient estimate is expected to be negative. The data on Return on Assets is retrieved from DataStream using the last reporting date before the acquisition announcement.

Next to the control variables used in the model, some other established variables are neglected in the model for various reasons.

Firm size is one of the most prominent variable mentioned in prior research (e.g. Park 2003)). It has shown that acquiring firms tend to be larger than non acquiring companies. Since the constructed dataset already incorporates by definition the comparison of active and non-active peer companies of similar market capitalizations in order to control for size biases, there is no need to include firm size as a variable.

Additionally, the number of prior acquisitions is often mentioned as being a factor in merger and acquisition processes (e.g. Haunschild (1993)). It appears that companies that had undertaken those processes in the past are more likely to continue to undertake these processes in the future. Frequently, some companies tend to define part of their business culture in an active merger and acquisition behaviour. Since the constructed dataset already excludes multiple acquirers, this variable will not be included in the model.

Furthermore, academic literatures have highlighted that merger and acquisition activities occur in waves, due to government regulatory efforts and specific macroeconomic situations (Andrade et al. (2001), Holmstrom and Kaplan (2001)). Also, it appears that some industries tend to be more active in merger and acquisition processes than others due to certain industry characteristics. Again, these two variables are not included in the model, since the constructed dataset already matches the active with their non-active counterparts in terms of the acquisition announcement date and the industry.

Table 2 summarizes the takeover theories described, the corresponding variables with the expected signs, and if applicable, the DataStream codes that were used to retrieve the necessary data.

[Table 2]

The subsequent section will present the empirical analysis using the constructed datasets. Firstly, descriptive statistics of the variables will be presented, followed by various binary logistic regression models. A binary logistic approach is used, since the independent variable Activity is defined as 1 for companies engaging in merger and acquisition activities and their inactive peer companies are coded 0. 


\section{$4 \quad$ Empirical Analysis}

This section will commence with descriptive statistics of the dependent variables of the models. The second part of the section will present the results on all the models under investigation. After all, the coefficient estimates of the models will help to answer the proposed hypotheses.

Tables 3 summarizes the standard descriptive statistics of the dataset. The table shows the means, standard deviations, and the correlations of the variables used in the models. Table 4 depicts nine significant correlations in total ${ }^{6}$. Nevertheless, the correlations are acceptably low and therefore, all variables can be used in the imminent regression analyses.

\section{[Table 3]}

Table 4 presents the results of the binary logistic regression models. It reports the results for the four different models in which the peer companies have shown a similar market capitalization one day prior to the acquisition announcement of the active company. With a view to greater clarity, the four models mentioned in Table 4 will be defined as models 1, 2, 3, and 4 .

\section{[Table 4]}

Model 1 identifies the variables Debt to Equity Ratio and Return on Assets as significant coefficients at the $1 \%$ level. Furthermore, the signs of the coefficients show the predicted negative relationship related to the probability to become active in merger and acquisition activities. The coefficients of the variables Current Ratio and the Market to Book Ratio show no significant results. Whereas the sign of the coefficient of the Market to Book Ratio still shows the expected negative relationship to the probability of activity in merger and acquisition processes, the coefficient of the Current Ratio even shows an unexpected negative sign. Nevertheless, since these coefficients are highly insignificant, there is no further need to elaborate on their impact in the analysis.

In Model 2, the corporate governance measure Governance Index is added to the control variables. Including this variable, Model 2 improves the explanatory power in compari-

\footnotetext{
${ }^{6}$ All significant correlations are listed in the explanation of Table 4 under the actual values.
} 
son to Model 1 from a Nagelkerke R Square of 21 percent to 25.1 percent. No change in signs of the coefficient estimates of the control variables can be detected and the Debt to Equity Ratio and the Return on Assets are still significant at the 1 percent level. The coefficient of the added variable Governance Index reports a positive significant value (0.156) at the 5 percent level as expected. Hence, this result shows support to the proposition that companies limiting the rights of their shareholders demonstrate a higher probability to become active in merger and acquisition activities.

Since the inclusion of the variable Governance Index have shown superior results in terms of the Nagelkerke's R Square, the variables will stay included in the analysis of related and unrelated acquisition activities. Those acquisition activities in which the active company acquirers a target company operating in the same GICS industry code is defined as a related acquisition and all acquisitions in which the GICS industry code of the target differs from the acquiring company is classified as an unrelated activity.

In the following, the results of the binary regression models are discussed, hence Models 3 and 4 are analysed, in which Model 3 presents the results concerning the related activities and Model 4 represents the unrelated activities.

Looking at the correlation matrices ${ }^{7}$, it becomes clear that the results of Model 4 need to be treated with great caution, since in three cases the control variables are highly correlated and would call for a change in the design of the model. Since this would change all the undertaken analyses, the model's structure is kept. Furthermore, the number of included observations, as shown in the output of Model 4, has remarkably decreased in comparison to Models 2 and 3, and gives further reason to question the representative ability of the Model and the Nagelkerke R Square. Nevertheless, if some insights were to be drawn from the conducted regressions, it appears that the control variables of the Models 3 and 4 in comparison to Model 2 have only shown a switch in signs concerning the Market to Book Ratio, and the coefficient estimate for this variable is not significant. Furthermore, the significant coefficient for the variable Debt to Equity Ratio has increased for the unrelated activities, possibly showing that a company with increasing sufficient resource availability might even be willing to take on more risk and even show a higher probability to become active in unrelated acquisition activities. Next, the significant Governance Index coefficient estimate (0.323) shows, as predicted, a higher probability to be engage in unrelated acquisition activities. Therefore, it

\footnotetext{
${ }^{7}$ Results not reported.
} 
could be derived that companies that allow their managers to take on more risky decisions show a higher propensity that these managers will do so. Nevertheless, as explained earlier, all these depictions are to a high extent ambiguous and therefore all possible effects are subjunctive.

The presented results in this section have shown mixed results with respect to the hypotheses. Even though the variable Return on Assets was treated as a control variable for prior performance measures, the results present support for hypothesis 1 . The presented results on the variable Governance Index have shown strong support for hypothesis 3. In Models 2, as well in Models 3, 4, the coefficients have shown significant evidence. To give a sound interpretation on hypotheses 2 and 4, the constructed models have suffered from correlations of the included variables and have lacked legitimacy due to the size of the sample. With great caution, some evidence for hypothesis 4 can be derived from the results, nevertheless, the prior performance variables gave no inferences on hypothesis 2 . The subsequent section will further discuss the results at hand, will detect limitations concerning the datasets and models, and will conclude.

\section{$5 \quad$ Limitations, Discussion and Conclusions}

The undertaken research results can provide an orientation for further research. There are limitations in the models' setups and additionally some shortcomings in the datasets. Concerning the model, it is obvious that there are further characteristics than the chosen variables that have an impact on the probability of a company to become active in merger and acquisition processes. Many of these are qualitative measures that are hard to incorporate in a statistical setup, for instance the overall mission statement of a company, which can have numerous implications on the business' approach concerning organic or inorganic growth. Further quantitative measures seem to be of interest. Morck et al. (1988b), Morck et al. (1990), and Powell (2004) highlight that it is necessary to account for differences in hostile and friendly takeover activities. Powell claims that the use of a binary approach, as used in the presented setup, will result in poorer predictive performance. The use of a multinomial approach should improve the models' significance and explanatory power. Furthermore, Morck et al. (1990), emphasise that it is necessary to account for multiple bidders in an analysis. Taken this into consideration, there might be companies in the created datasets of inactive companies that 
have also planned to become active, but have retreated in the way of negotiations. Additionally, the means of payment for the acquisition activities has not been taken into account in the setup of the model. Even though the chosen variables do show prior resource capacity of the bidding companies, the choice of using either cash or stock as a mean for the acquisition activity might shed additional light on the management's alacrity to take on more risk and on the governance structure of the company. Also, the constructed datasets do not specify the target company to a large degree. Next to the already mentioned differentiation on the affability of the takeover process, the Thomson Baker One Database on M\&A activities does not give information about the market values of the target companies. Therefore, the information given does not display the overall significance of the activity to the acquirer. The proportion of the target's market capitalization in comparison to the acquiring company's market capitalization would give additional information on the propensity of willingness to agree to risky manoeuvres. Hence this information might generate further insights on the corporate governance structure of the company. In addition, the constructed database does not take any geographical similarities of the acquirer and the target company into account. Plausibly, this attribute might explain the activity or the inactivity of companies, especially in industries that face high transportation costs. A potential target will therefore be more attractive to a potential acquirer that operates nearby, than for one that operates far away. Furthermore, the database does not depict if the target firm has been a previous subcontractor, which would considerably decrease the risk involved in the activity, since the subcontractor was most likely already acquainted with business policies of the acquirer. In addition, the dataset does not present any information on the previous stake the acquirer had in the target company. This aspect is in line with the missing information on the specific amount of costs incurred by the acquirer of the transaction as a whole. In addition, the model's setup does not include previous acquisitions of the acquirers by definition of the database's setup. Nevertheless, this variable has proven to have shown significant results in previous studies (Amburgey and Miner (1992), and Lehnert and Schüller (2005)). Including this variable were to have changed the database's setup, but might have increased the overall explanatory power of the models. Furthermore, the dataset's approach to identify related and unrelated acquisitions could be classified as a limitation of the model. The chosen 2-digit GICS classification depicts the acquisition activities as to be related to a large amount and a further refinement of the industries could lead to a different result. However, since the results of this approach are in line with the findings of Andrade and Stafford (2001), the setup does not diminish the legitimacy of the models. Finally, the created variable Governance Index by Gompers et al. (2001) might give 
reason to call for possible limitations concerning the expressiveness of the results at hand. Since all provisions that define the index are weighted equally, the approach might give reason to question the quantitative expression of the index. Taking the potential limitations of the model and the constructed dataset into account, the undertaken analysis could have shown more representative and possibly more significant results.

However, some of the depicted results are in line with previous research, show significant results, and underline to a certain extend the valid derivation of the hypotheses.

The conducted analysis on the factors driving merger and acquisition activities suggest that the probability to become active is related to poor prior performance, a well endowed financial situation, and weak shareholder rights of companies compared to their inactive peers.

Concerning the prior performance measure Return on Assets, the undertaken analysis supports hypothesis 1 and therefore also the results of Morck et al. (1990). Nevertheless, it needs to be mentioned that not all of the models show significant negative coefficients for the variable as expected. Only the models in the first dataset show mostly significant results, but also the results in the second dataset show consistently negative coefficients signs. From this point of view, hypothesis 1 can be seen as supported. Next, the included variable Debt to Equity Ratio, which was integrated to measure a firm's prior resource availability, shows strong support to the assumed relation on the probability to become active in merger and acquisition processes. This relation was not questioned by the stated hypothesis, since it appears to be one of the more established variables concerning the topic. The coefficient estimates of this variable support that companies that are well endowed in terms of financial resources, and in this case with a relatively higher proportion of equity towards debt in comparison to their peers, show a higher probability of getting active in merger and acquisition activities. Unanimously, the results show negative coefficient estimates and are in almost all results of the models significant.

Contrary to the rather long term measure of resource availability Debt to Equity Ratio, the Current Ratio's coefficient estimates show very inconclusive results. As all of the coefficients' estimates are insignificant and all of the estimates show a positive sign in the models of dataset 1, all of the coefficients estimates of dataset 2 show negative signs, no relation to the probability towards an activity in merger and acquisition processes can be made. Since the variable Current Ratio describes a company's short term liquidity, these results are not surprising, assuming that the hypothesis concerning the prior performance depicted from the 
variable Return on Assets is valid, because a presently experienced bad performance might have had an effect on companies' short term assets. Hence, no derivations can be made from the variable Current Assets in relation to the probability to become active in merger and acquisition processes.

Next, the variable Market to Book Ratio has shown some support for the predicted assumption that already established firms with limited opportunities to grow organically will show a higher probability to become active in merger and acquisition processes. Nevertheless, even though almost all coefficient estimates have shown the predicted negative signs, one being significant, it is rather hard to depict any valid assumptions from theses results. If any, then it could be stated that the variable confirms the predictions made.

Finally, the analysis of the variable Governance Index has shown very conclusive results for this study. As predicted, therefore in line with hypothesis 3, the coefficient estimates of the variable show in all but one model not just the depicted positive signs, but also significant values. Since the variable does not show any noteworthy results concerning possible correlations with any other included variables, the Governance Index has strong explanatory power. In line with the study of Gompers et al. (2001), companies with weaker shareholder rights show a higher probability of undertaking merger and acquisition activities.

With the results at hand, it is rather hard to derive an indisputable conclusion concerning hypotheses 2 and 4 . Due to the already described correlations of the variables in one of the datasets and the overall limited explanatory power due to the small sample of companies that became active in unrelated businesses, only very cautious interpretations can be made. Regarding the hypothesised increase of unrelated acquisition activities, with even weaker prior performance compared to other active companies, the results in the first and second dataset show not just mixed, but also mostly insignificant findings. Concerning the results for hypothesis 4, it can be depicted that an increase in the variable Governance Index can indeed explain an increase in the probability to become active in unrelated businesses. Both coefficient estimates have increased in comparison to the companies becoming active in related businesses. From these findings it can be derived that the weaker the rights of the shareholders, the higher the amount of risk that managers are willing to undertake and hence, they might even prefer to become active in unrelated fields.

Summing up, the performed analyses have found definite supportive results to hypotheses 1 and 3. Furthermore, the study has found results that give reason to support hypothesis 4, even though the analysed sample has lacked legitimacy. No results have been 
found to confirm hypothesis 2 . Therefore, the study has found evidence that the probability of a company to become active in merger and acquisition activities increases, the lower the company's prior performance and the weaker the shareholder rights in comparison to equivalent companies are. 


\section{Appendix: Governance Index Provisions}

This appendix is a reproduction from Gompers et al. (2001) and describes the 24 provisions that are used to construct the Governance Index. The construction of the index is very simple, since it adds one point for every provision that reduces shareholder rights.

Antigreenmail - Greenmail refers to the agreement between a large shareholder and a company in which the shareholder agrees to sell his stock back to the company, usually at a premium, in exchange for the promise not to seek control of the company for a specified period of time. Antigreenmail provisions prevent such arrangements unless the same repurchase offer is made to all shareholders or the transaction is approved by shareholders through a vote. They are thought to discourage accumulation of large blocks of stock because one source of exit for the stake is closed, but the net effect on shareholders is unclear (Shleifer and Vishny (1986)). Five states have specific antigreenmail laws, and two other states have "recapture of profits” laws, which enable firms to recapture raiders' profits earned in the secondary market. Gompers et al. (2001) consider recapture of profits laws to be a version of antigreenmail laws (albeit a stronger one). The antigreenmail category includes both firms with the provision and those incorporated in states with either antigreenmail or recapture of profits laws.

Blank check preferred stock - This is preferred stock over which the board of directors has broad authority to determine voting, dividend, conversion, and other rights. While it can be used to enable a company to meet changing financial needs, it can also be used to implement poison pills or to prevent takeover by placement of this stock with friendly investors. Companies who have this type of preferred stock but who have required shareholder approval before it can be used as a takeover defence are not coded as having this provision.

Business Combination laws - These laws impose a moratorium on certain kinds of transactions (e.g., asst sales, mergers) between a large shareholder and the firm for a period usually ranging between three and five years after the shareholder's stake passes a pre-specified (minority) threshold.

Bylaw and Charter amendment limitations - These provisions limit shareholders' ability to amend the governing documents of the corporation. This might take the form of a supermajority vote requirement for charter or bylaw amendments, total elimination of the ability of shareholders to amend the bylaws, or the ability of directors beyond the provisions of state law to amend the bylaws without shareholder approval. 
Classified board - A classified board is one in which the directors are placed into different classes and serve overlapping terms. Since only part of the board can be replaced each year, an outsider who gains control of a corporation may have to wait a few years before being able to gain control of the board. This provision may also deter proxy contests, since fewer seats on the board are open each year.

Compensation plans with changes in control provisions - These plans allow participants in incentive bonus plans to cash out options or accelerate the payout of bonuses should there be a change of control. The details may be a written part of the compensation agreement, or discretion may be given to the compensation committee.

Director indemnification contracts - These are contracts between the company and particular officers indemnifying them from certain legal expenses and judgments resulting from lawsuits pertaining to their conduct. Some firms have both "indemnification" in their bylaw/charter and these additional indemnification "contracts”.

Control-share cash-out laws enable shareholders to sell their stakes to a "controlling” shareholder at a price based on the highest price of recently acquired shares. This works sometimes like fair-price provisions extended to non-takeover situations.

Cumulative voting - Cumulative voting allows a shareholder to allocate his total votes in any manner desired, where the total number of votes is the product of the number of shares owned and the number of directors to be elected. By enabling them to concentrate their votes, this practice helps enable minority shareholders to elect favoured directors. Cumulative voting and secret ballot are the only two provisions whose presence is coded as an increase in shareholder rights, with an additional point to the Governance Index, if the provision is absent.

Directors' duties allow directors to consider constituencies other than shareholders when considering a merger. These constituencies may include, for example, employees, host communities, or suppliers. This provision provides boards of directors with a legal basis for rejecting a takeover that would have been beneficial to shareholders. 31 states also have laws with language allowing an expansion of directors' duties, but in only two of these states (Indiana and Pennsylvania) are the laws explicit that the claims of shareholders should not be held above those of other stakeholders. Firms in these two states are treated as though they had an expanded directors' duty provision unless the firm has explicitly opted out of coverage under the law.

Fair-Price Requirements - These provisions limit the range of prices a bidder can pay in two-tier offers. They typically require a bidder to pay to all shareholders the highest price 
paid to any during a specified period of time before the commencement of a tender offer and do not apply if the deal is approved by the board of directors or a supermajority of the target's shareholders. The goal of this provision is to prevent pressure on the target's shareholders to tender their shares in the front end of a two-tiered tender offer, and they have the result of making such an acquisition more expensive. This category includes both the firms with the provision and the firms incorporated in states with a fair price law.

Golden parachutes - These are severance agreements which provide cash and non-cash compensation to senior executives upon a triggering event such as termination, demotion, or resignation following a change in control. They do not require shareholder approval.

Director indemnification - This provision uses the bylaws/ or charter to indemnify officers and directors from certain legal expenses and judgements resulting from lawsuits pertaining to their conduct. Some firms have both this "indemnification” in their bylaws/charter and additional indemnification “contracts”. The cost of such protection can be used as a market measure of the quality of corporate governance.

Limitations on director liability - These charter amendments limit directors' personal liability to the extent allowed by state law. They often eliminate personal liability for breaches of the duty of care, but not for breaches of the duty of loyalty or for acts of intentional misconduct or knowing violation of the law.

Pension parachute - This provision prevents an acquirer from using surplus cash in the pension fund of the target in order to finance an acquisition. Surplus funds are required to remain the property of the pension fund and to be used for plan participations' benefits.

Poison pills - These securities provide their holders with special rights in the case of a triggering event such as a hostile takeover bid. If a deal is approved by the board of directors, the poison pill can be revoked, but if the deal is not approved and the bidder proceeds, the pill is triggered. In this case, typical poison pills give the holders of the target's stock other than the bidder the right to purchase stock in the target or the bidder's company at a steep discount, making the target unattractive or diluting the acquirer's voting power. The early adopters of poison pills also called them "shareholder rights" plans, ostensibly since they give current shareholders the "right” to buy additional shares, but more likely as an attempt to influence public perceptions. A raider-shareholder might disagree with this nomenclature.

Secret ballot - Under secret ballot (also called confidential voting), either an independent third party or employees sworn to secrecy are used to count proxy votes, and the management usually agrees not to look at individual proxy cards. This can help eliminate potential conflicts of interest for fiduciaries voting shares on behalf of others, or can reduce pressure by 
management on shareholder-employees or shareholder-partners. Cumulative voting and secret ballot are the only two provisions whose presence is coded as an increase in shareholder rights, with additional point to the Governance Index if the provision is absent.

Silver parachutes - These are similar to golden parachutes in that they provide severance payments upon a change in corporate control, but unlike golden parachutes, a large number of a firm's employees are eligible for these benefits.

Special meeting requirements - These provisions either increase the level of shareholder support required to call a special meeting beyond that specified by state law or eliminate the ability to call one entirely.

Supermajority requirements for approval of mergers - These charter provisions establish voting requirements for mergers or other business combinations that are higher than the threshold requirements of state law. They are typically 66.7, 75, or 85 percent, and often exceed attendance at the annual meeting. This category includes both the firms with this provision and the firms incorporated in states with a "control-share acquisition” law. These laws require a majority of disinterested shareholders to vote on whether a newly qualifying large shareholder has voting rights. In practice, such laws work much like supermajority requirements. Unequal voting rights - These provisions limit the voting rights of some shareholders and expand those of others. Under time-phased voting, shareholders who have held the stock for a given period of time are given more votes per share than recent purchasers. Another variety is the substantial-shareholder provision, which limits the voting power of shareholders who have exceeded a certain threshold of ownership.

Limitations on action by written consent - These limitations can take the form of the establishment of majority thresholds beyond the level of state law, the requirement of unanimous consent, or the elimination of the right to take action by written consent. 


\section{References}

Amburgey T. L., \& Miner, A. S. (1992). Strategic Momentum: The Effect of Repetetive, Positional, and Contextual Momentum on Merger Activity. Strategic Management Journal 13, $335-349$.

Andrade, G., Mitchell, M., \& Stafford, E. (2001). New evidence and perspectives on mergers? Journal of Economic Perspectives 15, $103-120$.

Barberis, N., \& Thaler, R. (2002) A Survey of Behavioral Finance. Working paper, University of Chicago

Bauer, R., Günter, N., Otten, R. (2003). Empirical Evidence on Corporate Governance in Europe: The Effects on Stock Returns, Firm Value and Performance. Limburg Institute of Financial Economics, Working Paper 03 - 023.

Baumol, W.,J. (1967). Business Behavior, Value and Growth. New York: Hartcourt, Brace \& World Inc. $2^{\text {nd }}$ ed..

Berger,P., \& Ofek, O. (1995). Diversification's Effects on Firm Value. Journal of Financial Economics 37, $39-65$.

Brigham, E. F., \& Daves, P. R. (2004). Intermediate Financial Management. Thomson South-Western $8^{\text {th }}$ ed.

Berkovitch, E., \& Narayanan, M.P. (1993). Motives for Takeovers: An Empirical Investigation. Journal of Financial and Quantitative Analysis 28, 347 - 362.

Bertsch, K. (2005). How Moody's Assesses Corporate Governance. The Corporate Governance Advisor January/ February 12 - 19.

Cadbury Committee Report (1992). Report of the Cadbury Committee on the Financial Aspects of Corporate Governance, Gee, London

Drake, D. S. (2003). Are You Ready for the Ratings Game? The Corporate Governance Rating Phenomenon. The Corporate Governance Advisor, January/ February 20 - 25.

Galpin, T.J., \& Herndon, M. (1999). The Complete Guide to Mergers and Acquisitions. Jossey-Bass Business \& Management Series, $1^{\text {st }}$ ed..

Gompers, P., Ishii J., \& Metrick, A. (2003). Corporate Governance and Equity Prices. Quarterly Journal of Economics 118 (1), $107-155$.

Hall, B. \& Liebman, J. (1998). Are CEOs Really Paid like Bureaucrats? Quarterly Journal of Finance 112 (3), 653 - 691.

Haunschild, P. (1993). Interorganizational Imitation: The Impact of Interlocks on Corporate Acquisition Activity. Administrative Science Quarterly 38, 564 - 592. 
Henry, D. (2002). Mergers: Why Most Big Deals Don't Pay Off. Business Week October 14, $60-70$.

Holstrom, B., \& Kaplan, S. (2001). Corporate Governance and Merger Activity in the United States: Making Sense of the 1980s and 1990s. Journal of Economic Perspectives 15, 121 144.

Information on company's financial data was retrieved from DataStream Universiteit Maastricht, in the period from March until June 2006.

Information on Merger and Acquisition Activities was retrieved from the Thomson Baker One M\&A Database on March 11, 2006.

Information on the Governance Index was retrieved from IRRC on May 16, 2006.

Jensen, M. (1993). The Modern Industrial Revolution. Journal of Finance 48 (3), 831-880.

Jensen, M. (1988). Takeovers: Their causes and Consequences. Journal of Political Perspectives 2 (1), $21-48$.

Kahneman, D., \& Tversky, A. (1979) Prospect Theory: An Analysis of Decision Under Risk. Econometrica 47, $263-291$.

Lang, L., \& Stulz, R. (1994). Tobin's Q, Corporate Diversification, and Firm Performance. The Journal of Political Economy 102, 1248 - 1280.

Lehnert, T., \& Schüller, F., (2005). On Performance, Aspirations and Risky Organizational Decisions: Evidence from Merger and Acquisitions, Limburg Institute of Financial Economics, Working Paper 05 - 005.

McKinsey (2002). The Global Investor Opinion Survey, Retrieved June $3^{\text {rd }} 2006$ form the World Wide Web: www.mckinsey.com/clientservice/.../Globalinvestoropinionsurvey2006.pdf

Morck, R., Shleifer, A., \& Vishny, R. (1988a). Corporate Takeovers: Causes and Consequences. Chicago: University of Chicago Press.

Morck, R., Shleifer, A., \& Vishny, R. (1988b). Characteristics of Hostile and Friendly Takeover Targets. Chicago: University of Chicago Press.

Morck, R., Shleifer, A., \& Vishny, R. (1989). Alternative Mechanisms for Corporate Control. The American Economic Review 79 (4), 842 - 852.

Morck, R., Shleifer, A., \& Vishny, R. (1990). Do Managerial Objectives Drive Bad Acquisitions? Journal of Finance 45 (1), 31 - 48.

Park, C. (2003). Prior Performance Characteristics of Related and Unrelated Acquirers. Strategic Management Journal 24, 471 - 480.

Ross, S.A., Westerfield, R.W., Jaffe, J. (1999), Corporate Finance, Irwin/McGraw-Hill, 
$5^{\text {th }}$ ed..

Powell, R. (2004). Takeover Prediction Models and Portfolio Strategies: A Multinomial Approach. Multinomial Finance Journal 8, 35- 77.

Roll, R. (1986). The Hubris Hypothesis of Corporate Takeovers. Journal of Business 59, 197 $-216$.

Schneider, S.C. \& Barsoux, J-L. (2003). Managing across cultures. Prentice Hall $2^{\text {nd }}$ ed..

Shleifer, A.,\& Vishny, R. (1986). Greenmail, white knights, and shareholder's interest. Rand Journal of Economics 17, 293 - 309.

Shleifer, A.,\& Vishny, R. (2003). Stock market driven acquisitions, Journal of Financial Economics.

Standardandpoors.com, Factsheet S\&P 1500 , Retrieved April $2^{\text {nd }} 2006$ from the World Wide Web: http://www2.standardandpoors.com/spf/pdf/index/Factsheet_sp1500.pdf.

Weir, C. (1997). Corporate Governance, Performance and Take-overs: An Empirical Analysis of UK Mergers. Applied Economics 29, 1465 - 1475. 
Table 1: Distribution of Active Companies across Industries

\begin{tabular}{lcc}
\hline & Active Compa- & Unrelated Acquisi- \\
Industry (GICS Code) & nies & 2 \\
\hline Energy (10) & 8 & 1 \\
Materials (15) & 4 & 7 \\
Industrials (20) & 23 & 4 \\
Consumer Discretionary (25) & 20 & 0 \\
Consumer Staples (30) & 3 & 4 \\
Health Care (35) & 10 & 0 \\
Financials (40) & 1 & 0 \\
Information Technology (45) & 13 & 0 \\
Telecommunication Services (50) & 1 & 1 \\
Utilities (55) & 9 & 19 \\
\hline Total & 92 & 2 \\
\hline
\end{tabular}


Table 2: Takeover Theories, Variables with Expected Signs and DataStream Definitions

\begin{tabular}{llcc}
\hline Takeover Theories & Variables & Expected & DataStream \\
Sign & Code \\
\hline Variables & & & \\
\hline Prior Resource availability & Debt to Equity Ratio & - & 733 \\
Prior Resource availability & Current Ratio & + & 741 \\
Low Growth & Market to Book Ratio & - & MTBV \\
Inferior Performance & Return on Assets & - & 707 \\
\hline $\begin{array}{l}\text { Inferior Corporate Govern- } \\
\text { ance }\end{array}$ & Governance Index & + & \\
\hline
\end{tabular}

The table shows the variables' definitions used to proxy the selected takeover theories. For the variables Debt to Equity Ratio Current Ratio, Return on Assets, and Governance Index the most current data possible prior to the acquisition announcement is used. The values of the variable Market to Book Ratio was taken exactly one trading day prior to acquisition announcement. 
Table 3: Means, Standard Deviations, and Correlations

\begin{tabular}{clcccccc}
\hline Variables & & Means & S.D. & 1 & 2 & 3 & 4 \\
\hline 1 & Debt to Equity Ratio & 0.650 & 0.979 & & & & \\
2 & Current Ratio & 2.085 & 1.463 & -0.116 & & & \\
3 & Market to Book Ratio & 2.994 & 2.737 & $0.155^{*}$ & $0.182^{*}$ & & \\
4 & Return on Assets & 11.040 & 8.367 & $0.294^{* *}$ & $0.147^{*}$ & $0.410^{* *}$ & $-0.188^{*}$ \\
5 & Governance Index & 9.407 & 2.565 & 0.018 & -0.134 & $-0.170^{*}$ & \\
\hline
\end{tabular}

*. Correlation is significant at the 0.05 level (2-tailed)

*. Correlation is significant at the 0.01 level (2-tailed)

The table reports the variables' means, standard deviations, and correlations. All data except the data on the Governance Index are expressed in percent. The values on the Debt to Equity Ratio, the Current Ratio, and the Return on Assets are calculated from yearly data, the values on the Market to Book Ratio are taken from daily data. There are 184 observations. 
Table 4: Binary Logistic Regression Models on Merger and Acquisition Activity

\begin{tabular}{|c|c|c|c|c|}
\hline \multirow[t]{2}{*}{ Variables } & \multicolumn{4}{|c|}{ Models } \\
\hline & 1 & 2 & 3 & 4 \\
\hline \multirow[t]{2}{*}{ Constant } & $1.815^{* * *}$ & 0.409 & 0.684 & -0.746 \\
\hline & $(0.507)$ & $(0.618)$ & $(0.895)$ & $(2.314)$ \\
\hline \multirow[t]{2}{*}{ Debt to Equity Ratio } & $-1.191 * * *$ & $-1.329 * * *$ & $-1.136^{* * *}$ & $-3.070 * *$ \\
\hline & $(0.364)$ & $(0.387)$ & $(0.410)$ & $(1.392)$ \\
\hline \multirow[t]{2}{*}{ Current Ratio } & -0.076 & -0.099 & -0.130 & -0.133 \\
\hline & $(0.124)$ & $(0.134)$ & $(0.154)$ & $(0.409)$ \\
\hline \multirow[t]{2}{*}{$\begin{array}{l}\text { Market to Book Ra- } \\
\text { tio }\end{array}$} & -0.009 & -0.003 & 0.001 & 0.189 \\
\hline & $(0.076)$ & $(0.078)$ & $(0.087)$ & $(0.250)$ \\
\hline \multirow[t]{2}{*}{ Return on Assets } & $-0.081 * * *$ & $-0.08 * * *$ & $-0.077 * *$ & -0.083 \\
\hline & $(0.026)$ & $(0.027)$ & $(0.030)$ & $(0.066)$ \\
\hline \multirow[t]{2}{*}{ Governance Index } & & $0.156^{* *}$ & $0.122 *$ & $0.323 *$ \\
\hline & & $(0.067)$ & $(0.074)$ & $(0.175)$ \\
\hline -2 Log likelihood & 222.254 & 215.448 & 176.275 & 31.111 \\
\hline Nagelkerke R Square & 0.21 & 0.251 & 0.209 & 0.577 \\
\hline Selected Cases & 184 & 184 & 146 & 38 \\
\hline \multicolumn{5}{|c|}{ Standard errors are given in parentheses under coefficients } \\
\hline \multicolumn{5}{|c|}{${ }^{*} \mathrm{p}<0.1 ; * * \mathrm{p}<0.05 ; * * * \mathrm{p}<0.01$} \\
\hline \multicolumn{5}{|c|}{$\begin{array}{l}\text { Nagelkerke } R \text { Square is the equivalent to the } R \text { Square in linear regression models and measures the explanatory } \\
\text { power of the model. The value ranges from } 0 \text { to } 1 \text {, the closer the value approaches } 1 \text {, the better the } \\
\text { model. }\end{array}$} \\
\hline
\end{tabular}

